\title{
IAMJ
}

INTERNATIONAL

AYURVEDIC

MEDICAL JOURNAL

(क) $\bigcirc(1$

Research Article

ISSN: 2320-5091

Impact Factor: 6.719

\section{A CROSS-SECTIONAL SURVEY STUDY TO ASSESS THE PREVALENCE OF PALITYA IN YOUTH WSR TO PRAKRITI}

\section{$\underline{\text { Temani Rashmi }}^{1}$,Sharma Surendra Kumar ${ }^{2}$}

${ }^{1}$ Lecturer Rog Nidana, Shekawati Ayurved College, Pilani, Rajasthan, India

${ }^{2}$ Professor Department of Rog Nidana, National institute of Ayurved Jaipur, Rajasthan

Corresponding Author: Rashmitemani@gmail.com

https://doi.org/10.46607/iamj0209092021

(Published Online: September 2021)

Open Access

(C) International Ayurvedic Medical Journal, India 2021

Article Received: 05/08//2021 - Peer Reviewed: 23/08/2021 - Accepted for Publication: 24/08/2021

\begin{abstract}
Ayurveda is a science of vast knowledge of Ahar, Vihar and Prakriti. In this modern era due to stress, lifestyle changes, eating habits and many psychological and environmental factors are responsible for premature greying of hair. The present cross-sectional survey study was planned to know about etiological factors of Palitya in youth and the prevalence of Prakriti also. Total 500 patients of premature canities fulfilling the criteria of inclusion as per GSS $^{1}$ were selected from O.P.D. of department Rog Nidana and Vikriti Vigyana, National Institute of Ayurved, Jaipur. A structured questionnaire will be administered to each subject of Nidanatmaka survey to collect data on Prakriti, Socio-demographic profile, Dietary patterns and other Ayurvedic variables. Results: Max. 37\% have Akala bhojana,36.4\% having Vishmagni,35 and 32\% habituated to Katu and Lavan Rasa,42\% consuming Amla Rasa, and max.36.4\% were having Vata-Pitta Prakriti. Overall, it was observed that in youth diet, dietary habits were prone to vitiate Pitta dosha. especially in the Pitta Prakriti persons. The faulty dietary habits like Vishamashana, Adhyashana, Ajeernashana, Amla-Lavana Rasa Atisevana can accelerate the process of greying hair.
\end{abstract}

Keywords: Premature canities, Prakriti

\section{INTRODUCTION}

In present days because of altered lifestyle and stressIncreasing urbanization and industrialization has ful occupation signs of ageing are seen much earlier. posed a greater danger, due to pollution and 
contamination of water and air, with variable both exogenous and endogenous factors, there is a definite increase in the incidence of Premature Greying of Hairs, especially in tropical and developing countries Incidence as per W.H.O ${ }^{2}$ is largely between the age group of 20-30 years. Accordingly, 'Akala Palitya' is such condition, which is prevailing more and increases more in day-to-day clinical practice. Unfortunately, contemporary medical science has some nutritional supplements for the treatment of premature greying of hair, but it does not offer satisfactory treatment, only temporary treatment is artificial dyeing with a chemical substance. Later on, it gets worse condition after going away for dyeing. This regular dyeing will lead to many adverse effects like hair fall and other scalp diseases. Understanding hair and related problems are not merely a cosmetic claim, but it reflects the psychological and pathological conditions of the whole-body system. But, when we look at Ayurveda for this problem, we have the best choice, because Ayurveda the 'Science of Longevity' promotes positive health, natural beauty, and long life.

Aim and Objective: This survey study was done to bring out etiological factors of Palitya into light, with the help of a questionnaire.

Material and Methods: Patients: A cross-sectional survey of 500 subjects of Premature Canities was taken from the OPD of Rog Nidana and Vikrati Vigyana in the National Institute of Ayurved Jaipur. The proper consent form was taken by the participants. A comprehensive survey incorporating the Ayurvedic Nidanatmaka factors with special reference to Prakarti as well as modern medical parameters will be conducted to find out the Prevalence of Palitya in youth (age 16- <40 years). A structured questionnaire will be administered to each subject of Nidanatmaka survey to collect data on Prakarti, Socio-demographic profile, Ahara Satmya (Dietary Pattern) and Sattva (Mental status) and other Ayurvedic variables.

Inclusion Criteria: The individuals having the age group between 16- <40.Patients with at least $25-50$ grey hairs in a particular area or in widespread in the scalp.
Exclusion Criteria: Individuals with any hormonal imbalance problems, any kind of fungal or other infection of the scalp. Individuals that having any major systemic disorder not included Pregnant and lactating ladies. Other skin disorders like Psoriasis, Eczema, Leukoderma etc.

Study Design: - Diagnosed patients of Palitya were included in the survey study. The diagnostic criteria of Palitya are as follows: Greying assessment in Palitya (Premature canities)- GSS (greying scoring system) evaluate the extent of greying taking into five representative sites from the scalp by 2 independent investigators and analyze for agreement. In this process the entire scalp surface divides into 5 zones, that is a frontal region, vertex, right and left temporal regions and the occipital. A $1 \mathrm{~cm}^{2}$ area mark with a skin marker and the hair within this square crop to approximately $1 \mathrm{~mm}$ above the scalp surface. Based on hair count, a score will be assigned to each zone according to the percentage of grey hairs in each square. This is calculated as score as Score 1 (assign to under 10\% grey hairs $\left./ \mathrm{cm}^{2}\right)$, Score $2\left(10-30 \%\right.$ grey hairs $\left./ \mathrm{cm}^{2}\right)$, Score 3 (more than $30 \%$ grey hairs $/ \mathrm{cm}^{2}$ )

Observations and Results: 500 patients were registered for the present study. The data showed that most of the patients $30 \%$ patients belonged to the age group 31-35 years followed by $24 \%$ belonged to $26-30$ years. Maximum patients were female that is $63.6 \%$, maximum $71 \%$ of patients were Hindu, maximum of $56 \%$ patients were married, the maximum numbers of patients $56 \%$ belonged to upper-middle class, among dietary habits of $64 \%$ patients were Vegetarian, 37\% were having Akala Bhojana, $36.4 \%$ patients were having Vișamagni, maximum $63.6 \%$ patients had addicted to tea, majority of patients i.e. $35.6 \%$ were habituated to Katu Rasa, 32\% patients to Lavana Rasa, 26\%,42\% were found to take Amla Rasa sometimes, 52\% were found to take Katu sometimes, $56.8 \%$ were found to take Ati lavana sometimes, The maximum no. of patients was found to be Vata-Pitta Prakrti i.e. 36.4\%., Among a total of 500 patients, $35.2 \%$ were found to take junk food Rarely while $28.4 \% \%$ were found Sometimes consumers, $58.8 \%$ were found doing 
excessive Krodha, $41.2 \%$ were found doing excessive tension sometimes.

\section{Observation of Chief Complaints:}

\begin{tabular}{|l|l|l|}
\hline Chief complaints & No. of patients & percentage \\
\hline 1. Kesha Varna (colour of the hair) & 500 & \\
\hline i.Krishna Varna & 0 & 0 \\
ii. Ash coloured & 100 & 20 \\
iii. Off-white & 150 & 30 \\
iv. White hairs & 250 & 50 \\
\hline 2.Kapaldaha 4 (Burning sensation in the scalp) : & 170 & 34 \\
\hline 3. Swedapravrti on forehead and scalp (sweating) & 155 & 31 \\
\hline 4. Ruksha Sphutita Kesha (dry and split hair) & 234 & 46.8 \\
\hline
\end{tabular}

\section{DISCUSSION}

At the time of the Samgraha period cosmetic consciousness might have increased. Acharya $\mathrm{Sa}$ rangdhara of that period quotes the perfect definition of Akala Palitya. Selection of Palitya disease is taken because of in this Vyadhi characteristic symptom is whitening or greying of hair by the Paka process of Pitta commenced especially by its Uṣna and Tikṣhṇa Gra The etiological factor for Akala Palitya is categorized basically into three types Aharaja, Viharaja, Manasika Nidana. Aharaja Nidana i.e excess use of Pittavardhaka Ahara, Viharaja Nidana are suppression of natural urges, Aatapa Sevana, Ratri Jagarana etc and manasika Nidana like excessive Krodha Shoka Bhaya Manasika Srama etc, all these factors provoke body heat and vitiated Pitta Doșha is carried to the Sirahpradesha by vitiated Vata where it performs Paka of hair hence the colour of hairs turn white. Palitya is a very common disease with a great prevalence rate. It affects the Hairs. Palitya is categorized under a different type of disease by various Acharya. It is explained as Kapalarogaby Sharangahara Kșhudra Roga by Bhavaprakash ${ }^{5}$, Madhava Nidana $^{6}$ \& Chakradatta ${ }^{7}$ and Shiroroga by Vagbhatta. The description of Palitya in Ayurveda corresponds well with theclinical picture of premature canities i.e. premature greying of hairs. Modern literature describes premature Canities may occur alone as an autosomal dominant condition or in association with the various autoimmune or premature ageing syndrome. Reduction in melanogenically active melanocytes in the hair bulb of grey anagen hair follicles with resultant pigment loss is central to the pathogenesis of greying. The Dravya which are having Madhura, Tikta, Kașhaya Rasa Sitata, Rukșa, Guru Guna and Dipana Pachana and Vata PittaShamaka properties and also having Keshranjana and Keshya Guna, are choice of drugs for the treatment of Palitya. The Ayurvedic Samprapti Prakriya of Nija Rog is based on six different kriya kala and efforts were made to sketch Palitya Samprapti in its accordance. Tridoșha Samchya Prakopa and Prasara gets the Sthanasamsraya with the association of specific Dushya in specific Srotasa and finally manifest the disease by unloading of Dhatu Mala on the two kala of Twacha Udakadhara and Asrrgdhara, especially on Sirahah Kapala.

Acharya Sushruta in Nidana Sthana 13/36 given a specific Samprapti of Palitya and said thatpitta is the dominant dosha in Palitya. due to causative factors like Krodha, Shoka and Srama, Pitta Doṣha is aggravated and thereby increases Pittoșma and Sariroșma. Vata which is also aggravated by Shoka and Srama carries this Pittosma to the Shiras. Sthanika Kapha is also get vitiated as the Shiras is the important location of Kapha. Thus, vitiated Tridoșha settled in the Romakupa (Sthnasamsraya). Locally settled Tridoșha further vitiate locally Bhrajaka Pitta, which gives colour to the hair. In this way, the natural colour of the hair is affected and Akala Palitya is caused. Acharya Vagbhatța has been quoted Palitya Vataja, Pittaja, Kaphaja, Dvandaja \& Tridoṣh which having symptoms according to dosha. All the three Brihattrayi Grantha which are the most prestigious 
texts in Ayurveda have given almost similar etiopathology about Palitya. In the first chapter, we revised the literature about Palitya in all available Ayurvedic texts and then formulated Nidana according to the Lakshana of the disease with the help of the concept given in Nidana Sthana. The data was collected on Prakrti, Socio-demographic profile, Ahara Satmya (Dietary Pattern) and Sattva (Mental status) and other Ayurvedic variables in the form of a Questionnaire.

\section{CONCLUSION}

It can be concluded from the etiopathological study that most of the etiological factors for Palitya are very much prevalent in the society like the use of Atiguru Aahara, Dugdha, Dahi, Rukșa, Shita, Vidahi, Snigdha, Dhüma, Diwaswapna, Ratrijagrana, Adhyayan, Chinta, Shoka, Krodha, bhaya, shittaUṣna -Akrama Sevana, are mainly related to today's lifestyle, hygiene-related issues, and circumstances.

\section{REFERENCES}

1. Singal A, Daulatabad D, Grover C. Greying Severity Score: A useful tool for evaluation of premature canities. Indian Dermatol OnlineJ 2016; 77:164-7

2. Krishna M, G Sivaram, $S^{3}$ Malini, A Review of Ayurvedic herbs with Keshranjan Property in the Management of Canities (Paliya) International Journal of Ayurvedic Medicine,2018,9(1),9-12

3. Bramhanand Tripathi, Sarangdhara Samhita, Purv Khand 7th chapter, Shloka number 152; Chaukhamba Surbharti Prakashan, Varanasi 2010 Edition, page number-114

4. Bramhanand Tripathi, Astanga Hridaya, Uttar Sthana $23^{\text {rd }}$ chapter, Shloka number 1-2; Chaukhamba Sanskrit Pratishthan, Varanasi 2014 Edition, page number- 1050

5. Shri Brahma Sankara Mishra, Bhavprakash, Uttarardha 61-chapter, Shloka number 1; Chaukhamba Sanskrit Bhawan, Varanasi-2001 Edition, page number-585

6. Shri Vijayrakshit and Kanthdatta, Madhav Nidana $55^{\text {th }}$ chapter, Shloka number 32; Chaukhamba Sanskrit Sansthan, Varanasi-2014 Edition, page number306

7. PT. Bhramshankar Mishra, Chakradatta, $55^{\text {th }}$ Chapter,
Shloka number 125-126; Chaukhamba Sanskrit Series office, Varanasi-2010 Edition, page number-435

8. Shri Gayadaash Sushruta Samhita, Nidanasthana Kshudrarognidana $13^{\text {th }}$ chapter, Shloka number37; Chaukamba Orientalia Varanasi-2010 Edition, page number-855

\section{Source of Support: Nil Conflict of Interest: None Declared}

How to cite this URL: Temani Rashmi \& Sharma Surendra Kumar: A Cross-Sectional Survey Study To Assess The Prevalence Of Palitya In Youth wsr To Prakriti. International Ayurvedic Medical Journal \{online\} 2021 \{cited September 2021\} Available from: http://www.iamj.in/posts/images/upload/1929_1932.pdf 